\title{
Isolation and identification of restriction endonuclease BsiSI
}

\author{
Mary Rina and Vassilis Bouriotis* \\ Institute of Molecular Biology and Biotechnology, Enzyme Technology Division, PO Box 1515, \\ Heraklion 711 10, Crete, Greece
}

Submitted February 13, 1990

BsiSI, an isoschizomer of HpaII (1) has been purified from Bacillus stearothermophilus species. BsiSI recognises the sequence 5'-CCGG-3' and cleaves between $\mathrm{C}$ and $\mathrm{C}$. The enzyme was purified using the following chromatographic steps: 1) Phosphocellulose, 2)Heparin-Agarose. The enzyme was free of contaminating nuclease activity. After 10 fold overdigestion on lambda DNA greater than $95 \%$ of the DNA fragments can be ligated and greater than $95 \%$ can be recut by BsiSI. Optimal conditions for BsiSI activity are $100 \mathrm{mM} \mathrm{NaCl}, 50 \mathrm{mM}$ Tris$\mathrm{HCl} \mathrm{pH} 7.5,10 \mathrm{mM} \mathrm{MgCl} 2$ at $55^{\circ} \mathrm{C}$. The fragments produced by BsiSI digestion of lambda DNA, Adeno 2, PRB322 and SV40 match those predicted by cleavage at the sequence CCGG (figure 1, lanes 2-6). Vector Bluescript KSII which contained recognition sites for the enzyme in the polylinker region, was digested by the enzyme BsiSI then annealed with forward or reverse sequencing primers and extended with Klenow enzyme in the presence of $\alpha^{32} \mathrm{P}-\mathrm{dATP}$. Dideoxy sequencing reactions were performed at this region with the same primers and run in parallel with the extended products (2). Results in figure 2 show that extended products of the forward (lane F) and the reverse (lane $\mathrm{R}$ ) sequencing primers comigrate with the band corresponding to the first $\mathrm{G}$ in the $5^{\prime}$-CCGG-3' sequence. Therefore BsiSI recognises and cleaves the following sequence.

$$
\begin{aligned}
& \text { 5'-C \CGG-3' } \\
& 5^{\prime} \text {-GGC }{ }^{\prime} \text { C-5' }
\end{aligned}
$$

\section{REFERENCES}

1. Sharp,P.A. et al. (1973) Biochemistry 12, 3055-3063.

2. Tabor,S. and Richardson,C.C. (1987) Proc. Natl. Acad. Sci. USA 84, 4767-4771.

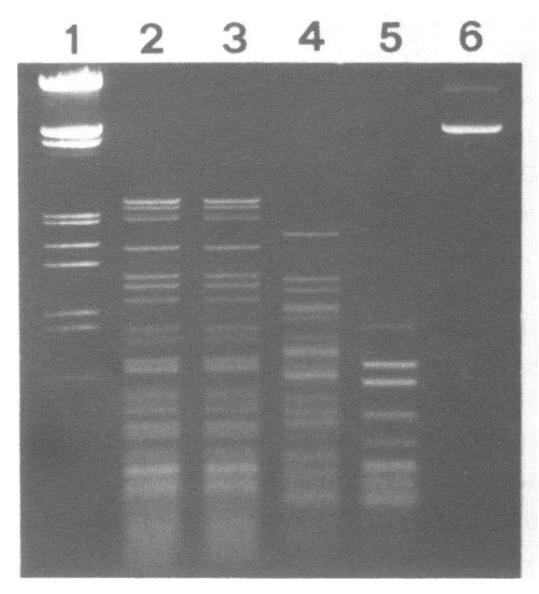

Figure 1. BsiSI digests; lane 1: lambda HindIII-EcoRI size standard, 2: lambda DNA digested by HpaII 3: lambda DNA, 4: Adeno 2, 5: PBR322, 6: SV40.
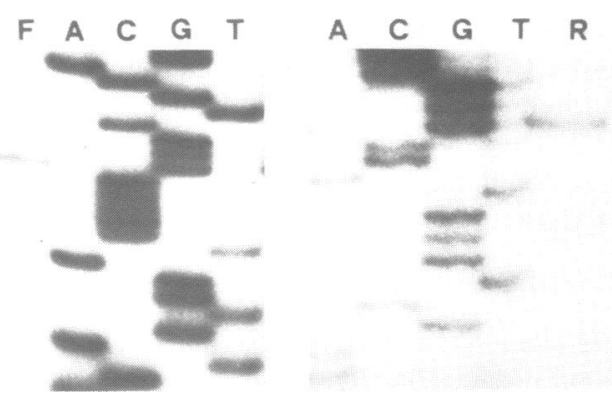

Figure 2.

\footnotetext{
* To whom correspondence should be addressed
} 